\title{
Saving Structure, Speculation Housing and Economic Growth in the Iranian Economy
}

\author{
Arash Refah-Kahriz \\ Urmia University \\ Yousef Mohammadzadeh ( $\nabla$ yo.mohammadzadeh@urmia.ac.ir) \\ Urmia University
}

Research

Keywords: Saving structure, Economic Growth, Housing, Speculation, Iranian Economy

Posted Date: November 20th, 2020

DOI: https://doi.org/10.21203/rs.3.rs-108810/v1

License: (9) This work is licensed under a Creative Commons Attribution 4.0 International License. Read Full License 


\title{
Saving structure, speculation housing and economic growth in the Iranian
} economy

\author{
Arash Refah-Kahriz, Yousef Mohammadzadeh* \\ Department of Economics, Urmia University, P. O. Box 165, Urmia, Iran \\ Arash Refah-Kahriz \\ arash.refah@gmail.com \\ Yousef Mohammadzaheh \\ yo.mohammadzadeh@urmia.ac.ir
}

* Corresponding author 


\title{
Saving structure, speculation housing and economic growth in the Iranian economy
}

\begin{abstract}
Economic theories maintain that saving is a significant financial resource for financial investment and economic growth; however, its structure has received little scholarly attention. If the structure of saving contributes into economic sterilization, it may result in undesirable consequences. This study investigates the relationship between saving structure, speculation housing and economic growth in Iranian economy, experiencing a high level of saving in the period 1970-2016. The results indicate that saving did not contributed into economic growth in Iranian economy; instead, a large proportion of saving was directed into speculation activities accumulating in the form of land and housing sector. During the time, this action increased the housing and land price index, much more than the total price index in Iranian economy. Therefore, it would be considerably difficult to start a business since the land is expensive; moreover, Iranian households assign a considerable amount of their money to housing and land section casing economic stagnation in other economic sections. Hence, despite the fact that Iran enjoys a high level of saving, it constantly suffers from enough budget resources for financial investment.
\end{abstract}

JEL: D14. D84. O16. O47

Keywords: Saving structure; Economic Growth; Housing; Speculation; Iranian Economy 


\section{Introduction}

The cycle of resources, among households, firms, government, and outside world, is one of the most important arguments in macroeconomics. Household income is saved or spent on purchasing companies' products. The government or foreign investors also receive the individuals' saving as taxes and imports. In this cycle, saving is considered as a leakage which could be reinvested in the business cycle (economic cycle) by financial institutions (Dornbusch et al, 2011).

Household saving is the saving that people perform for different purposes such as, life-cycle coverage, intertemporal substitution, inheritance, and precaution (Attanasio, 1993; Browning \& Lusardi, 1996; Friedman \& Warshawsky, 1990). It is argued that saving behavior is partly associated with macroeconomic situations like uncertainties (Blanchard \& Giavazzi, 2006; Chamon et al., 2013). Households' attitudes and perception toward the factors such as, economic markets, financial intelligence, and economic literacy could also impact on their saving behavior (Lusardi, 2008). Furthermore, the individuals' characteristics and their recognition abilities might determine their saving behaviors as well (Ballinger et al., 2011).

As mentioned above, saving is viewed as a leakage in economics; however, its reinvestment to economic cycle is one of the main arguments in macroeconomics (Mankiw, 2010). Theories on economic growth (e.g., Solow growth theory, Solow, 1970) contend that high saving rate increases the production and capital levels, and it promotes higher levels of longterm growth. That is, the amount of increase in saving rate is interpreted as investment growth which could improve the productive capacity of economy and capital stock. In other words, if saving is only used to compensate for depreciation of the capital, then no economic growth occurs (Snowdon \& Vane, 2005).

The relevant literature indicates investigations examining the relationship between saving, interest rate, investment, and economic growth. These studies support the theory of endogenous neoclassic and post-neoclassic in economic growth, and the findings consider the saving as the major factor in capital formation and economic growth (Attanasio et al., 2000; Fry, 1980; Odhiambo, 2009; Schmidt-Hebbel et al., 1996). Accordingly, it is proposed that individuals reinforce savings accumulation for capital formation and economic growth (Singh, 2010). The development theories consider saving deficiency as a main reason for the malady of poverty. For instance, underdevelopment trap theory articulates that poor countries do not have enough income sources for saving and investment, and due to the low rate of 
saving and investment, these countries cannot build and accumulate wealth and, thereby, they get into the trap of underdeveloped economics' malady.

Sinha and Sinha (2008) classified saving into three categories including household saving, public saving, and corporate saving. The effect of each particular saving is separately investigated on economic growth. Generally, there is not a common consensus among the researchers whether it is the economic growth which leads into the saving increase or it is the increase in the level of saving which brings about economic growth (Agrawal, 2001). However, it is generally discussed that the rate of saving is commonly in higher proportion in countries with higher income and economic growth (Ogaki et al., 1996). That is, saving could be considered as one of the main factors in promoting the rate of economic growth (Gavin et al., 1997).

Banking and financial systems also determine the individuals' saving behavior since the roles of these financial institutions are significant in managing and directing the amount of savings (Athukorala \& Sen, 2004).

Therefore, saving is considered as one of the significant arguments in the discussion and development of economic growth theories. The common answer to question of "why the countries experience high economic growth?" is that these countries experience the high level of savings. This issue has been emphasized in theories of economic growth, such as the theory of Solow growth.

However, the following questions could be arisen: to what extent the constant increase of saving could promote the level of economic growth? Is the constant increase of saving right or wrong? Is there a favorable level of capital that may demarcate the level of saving in a particular economic context? These sorts of questions motivated the economists to propose the Golden rule theory. This theory articulates that saving is favorable to the extent to which the consumption and, in fact, the social welfare could be maximized (Romer, 2012).

Still, another significant question is that whether the increase of saving level might be unfavorable. John Maynard Keynes benefited golden rule theory to explain the Great Depression in 1929 (Hunt, 2003). He argued that, in long run, continuous flow of saving and investment was not possible since the amount of investment, which was required for saving absorption, could increase the capital level, thus, promoting the production capacity. According to his statement, this capacity could increase the production and income levels in subsequent cycles.

However, an increase in income would result an increase in saving rate which requires further investment. To increase the total income of the society, individuals need to increase saving to 
a large proportion because in each new level of higher income a remarkable percentage of it is saved. Accordingly, the amount of investment should be larger than the income to continuously compensate for the saving leakage.

However, the necessary investment facilities are usually limited in every market-based economy making it much more difficult to simultaneously find enough investment resources during the process of economic growth. If it is not possible to find new investment channels, the investment level will be less than saving and the total costs of goods and services will be lower than their production's values. Therefore, the companies are not able to sell all their products and they need to continuously reduce their production level in subsequent periods (Hunt, 2003).

Generally, research on saving focuses on the consequences of both inadequate and excessive rate of saving and its optimal level. However, this line of inquiry has dedicated little attention to the structure and the type of saving. The question arisen in developing countries, including Iran, is that to what extend will saving rate disturb the markets if it is diverted into speculative investment rather than productive investment?

One may also ask the question of will the savings lead into the financial resources deficiency in production section if the savings are flown into the unproductive investment"? Therefore, it is theoretically expected that saving in subsequent economic cycles results in higher economic growth. However, little attention has been paid to its structure and the possibility of its flow into investment. That is, if saving is formed but due to its structure it is not led to investment, then, can we consider saving as a key factor in economic growth jump? Or will economic growth not be challenged with serious obstacles if saving is directed toward unproductive economic sections?

The aim of the present paper was to answer to a paradox existing in Iranian economy. The paradox is that Iran's economy usually experiences a lower position both in economic growth and investment despite its high level of saving rate. This study examined the flows and direction of saving in order to unravel this paradox in Iranian economy. Housing and land are two key sections elaborating on factors causing saving sterilization in Iran economy. In order to protect their saving rate, Iranian households flow their savings into speculative activities in housing and land markets rather than productive investment or consumptions. Due to the considerable time and money that Iranian households spend on housing and land purchasing, it could be easily justified that why Iranian economy experiences significant deficiencies in other sectors. Thus, this question would be arisen that could this sort of Iranian saving 
behavior contribute into sudden leap prices in Iranian housing market (even higher than the total price index)?

The relevant literature showed that some previous works investigated the impact of housing prices on individuals' saving (e.g., Disney et al., 2002; Engelhardt, 1996). This study is of significance since, as far as the researchers have investigated, no study has investigated the effect of Iranian household saving on house prices.

After articulating the research problem mentioned above, the rest of the paper is divided as follow: section 2 gives an explanation on the structure of saving in Iran's economy. Section 3 is dedicated to methodology. Section 4 describes the data and estimation results of long-term relationship between saving and economic growth and also, one of the most important sections of households' budget (i.e., housing), which somehow demonstrates the structure of saving in Iran's economy. Section 5 discusses on the consequences of such a situation in Iranian economy. Section 6 concludes the study.

\section{The structure of saving in the economy of Iran}

The current saving level (as a percentage of GDP) in Iran's economy (approximately 37\%) is in high proportion in comparison to saving rate averages found in the world (25\%), OECD countries (22\%), and even the Middle East economies (30\%) (World Bank, 2016). When the economic growth models such as Harrod-Domar ${ }^{\dagger}$ were introduced to developing countries including Iran, it was expected that the concentration on saving rate determination would be adequate to achieve the prescribed economic growth. For example, In Iranian third development plan (1962 - 1967), it was expected that the level of saving be increased from $18 \%$ to $25 \%$ for economic growth. Therefore, based on macroeconomics courses, it seems that investment resources are abundant in Iranian economy leading to a higher economic growth. However, it does not occur in reality. Despite these high levels of savings, over the past decades, Iran's economic growth has been faced with many challenges, and it has not experienced an increasingly long-term, sustainable development (it has fluctuated around the zero line). Figure 1 shows the savings trend, fixed capital formation, and GDP per capita growth in the economy of Iran.

\footnotetext{
$\uparrow$ The classical Harrod-Domar model is expressed as follow: $g=(\mathrm{s} / \mathrm{v})$, where $\mathrm{g}$ represents economic growth, $\mathrm{v}$ is the ratio of capital to production, and s denotes the saving rate (e.g., Chowdhury.\& Kirkpatrick, 2005).
} 


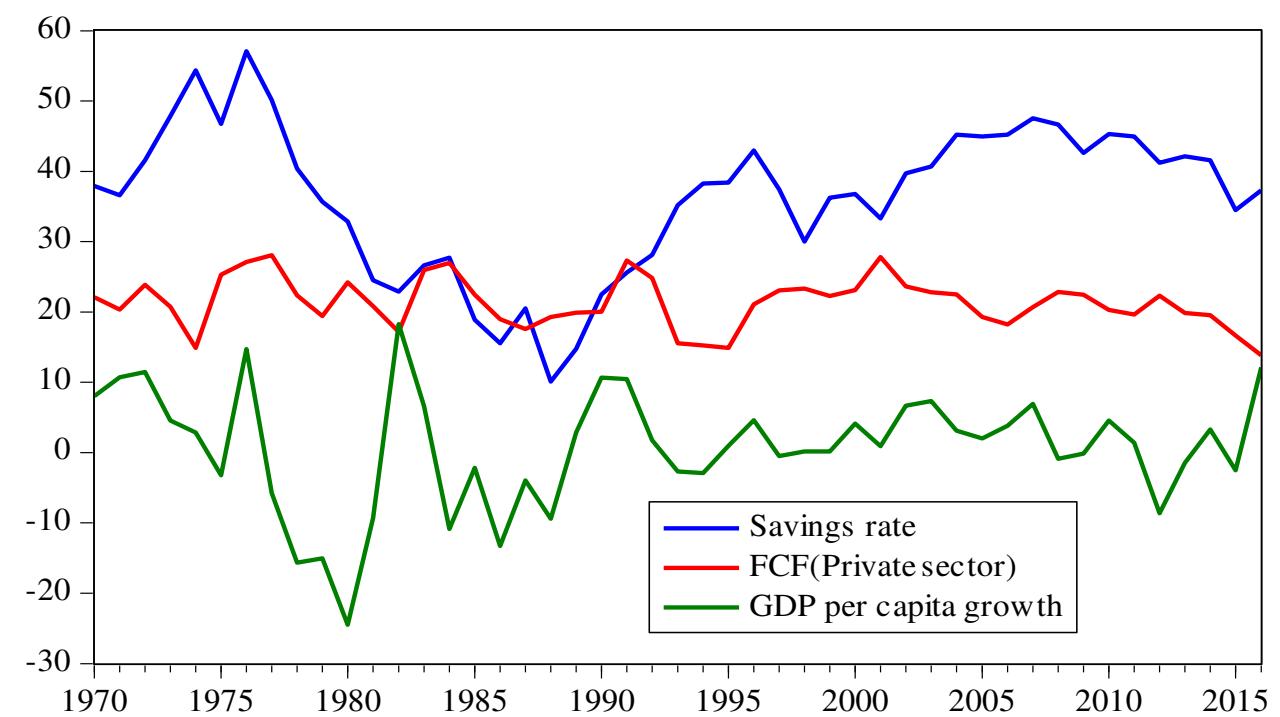

Figure 1: The trend of savings rate, fixed capital formation, and GDP per capita growth in

Iran (from 1970-2016)

Source: World Development Indicators

Figure 1 shows that there may not be a positively strong relationship between saving, capital formation, and economic growth; rather, in most periods seems an inverse relationship. Therefore, it creates us with the temptation to conclude that the macroeconomics courses, economic growth theories, and current development discussions on savings (i.e., the more savings, the higher economic growth) do not support the status of Iranian economy. This is a serious contradiction in the economy of Iran.

An unusual aspect of this paradox is that the global competitiveness reports considered the lack of financial resources as a serious problem in Iran's business flourishing during the years of 2010 - 2017 in spite of its relatively high levels of savings and huge oil revenues (World Economic Forum's Global Competitiveness Report).

How can such a paradox be explained in the economy of Iran? Investigation on the structure of investment in Iranian economy may not provide us with insightful understandings to elaborate on the causes of this phenomenon. Instead of exploring this paradox in the structure of Iran's economy, it would be logical to seek the causes of this contradiction in the structure of Iranian economy and the ways through which people protect their savings. Indeed, the question is that whether the savings are converted into productive investment or find their ways into speculative activities.

Two economic behaviors, practiced by Iranians, should be taken into consideration: the dominance of speculation activities in land and housing market and the accumulation of savings in this section. The first, concerns with the general speculative behaviors of Iranians 
directing their savings toward unproductive sections. In order to protect their savings, Iranian people show a high tendency to keep gold jewelry and foreign currencies, particularly when the value of the national currency is falling. Gold buying has increased by $202 \%$ in Iran's economy which has led the price be increased 3 times more in the past months. This particular behavior has motivated people to withdraw their small savings from bank deposits as well as production sections, causing saving sterilization in Iranian economy. Of course, this study does not analyze this issue statistically.

Iranians' savings aggregation behavior is traditionally grounded on Iranian culture, in which people tend to save their money in the form of land and housing. Investigating the economy of Iran, Richard Benedick (1961), one of the counselors from Harvard University, argued that investment on land and housing was a serious rival for industrial investment in Iran. He concluded that Iranian citizens were strongly motivated to maintain their savings accounts by investing on land and housing market.

Even years after the Islamic Revolution, price increases in land and housing market confirm the people's intense interest in transforming savings into land and housing. Housing and land price indices were increased much more higher than the total prices index during the recently periods. The growth in the rate of price indices obviously shows the high level of profitability in this section in comparison to other markets in Iranian economy, which might be due to the flow of large amounts of savings toward land and housing market.

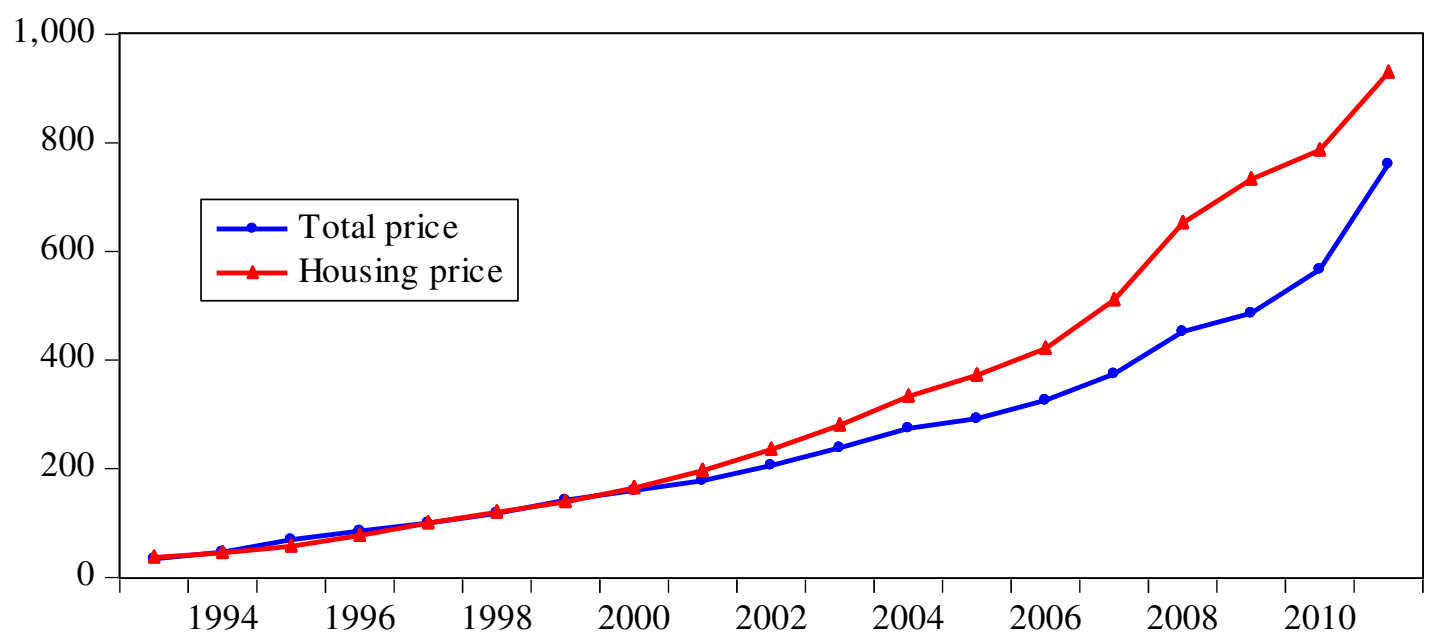

Figure 2: The trend of housing price compared to the total price index Source: Central Bank of Islamic Republic of Iran

There are several reasons elaborating on the people preferences to this economic behavior and its consequential damages on Iranian economic growth. These factors are people' view to Iranian economic instability, the constant increase of price in land and housing section, and 
the preference of some policymakers in meeting their financial interests. This economic behavior (i.e., flowing saving to housing and land market) is probably a serious challenge to Iranian economic growth, and it should receive due attention in developing economic plans. Land is a key requirement for most investments; however the costs of land preparation are too high for investment, which seriously limit the flow of investments and entrepreneurships in Iranian economy. In other words, buying and preparing the investment site imposes huge costs on the investor, which consequently brings about serious limitations in his/her business development. The price jump in land and housing market consume a large amount of money. This sudden price leap has resulted in, capital stagnation in this market, which is considered as the main reason for financial resource deficiencies in Iran economy in spite of Iran's high levels of savings and large oil revenues. Most of the Iranian people convert their incomes into lands and different types of houses, hence, the luxury and empty houses are the most distinctive characteristics of urban economy in Iran.

Another point is the volume of housing expense ratio in Iranian household budget. Iranians allocate a large amount of their incomes toward buying houses, and, therefore, they may experience inadequate money to meet the other various household needs (Figure 3). Figure 3 merely shows the proportion of money that Iranian households spend on house purchasing. Iranians also set aside a considerable amount of their expenditures on house renting.

The report on urban household budget by Iran's Central Bank in 2015 indicates that the share of housing was amounted to $35 \%$ out of total gross expenditures, an unprecedented record since 1991. According to the annual reports of Central Bank on Iranian household budget, housing share was approximately 1470000 Rials, accounted to $28 \%$ of total expenses, in the cost backsets of urban areas in 1991. This condition was fluctuating between 26-27\% during 1990-2004. However, in 2004, it suddenly increased to full $30 \%$ rate and finally reached to its highest level (i.e., 35\%) in 2016.

During the past decades, due to the rapid increases in home prices, it has been always difficult both for ordinary people and salaried employees to buy houses since home prices are being constantly increased not in congruence with the individuals' incomes and salaries. For example, in the current economic conditions, if an ordinary employee wants to buy a 100 square-meter apartment in the cheapest places in Tehran, he/she has to pay for an amount of money, which is equal to the sum of all his/her income obtained during the next 20 years (of course the prices are constantly increasing as the time passes; providing that the home prices are stable). 


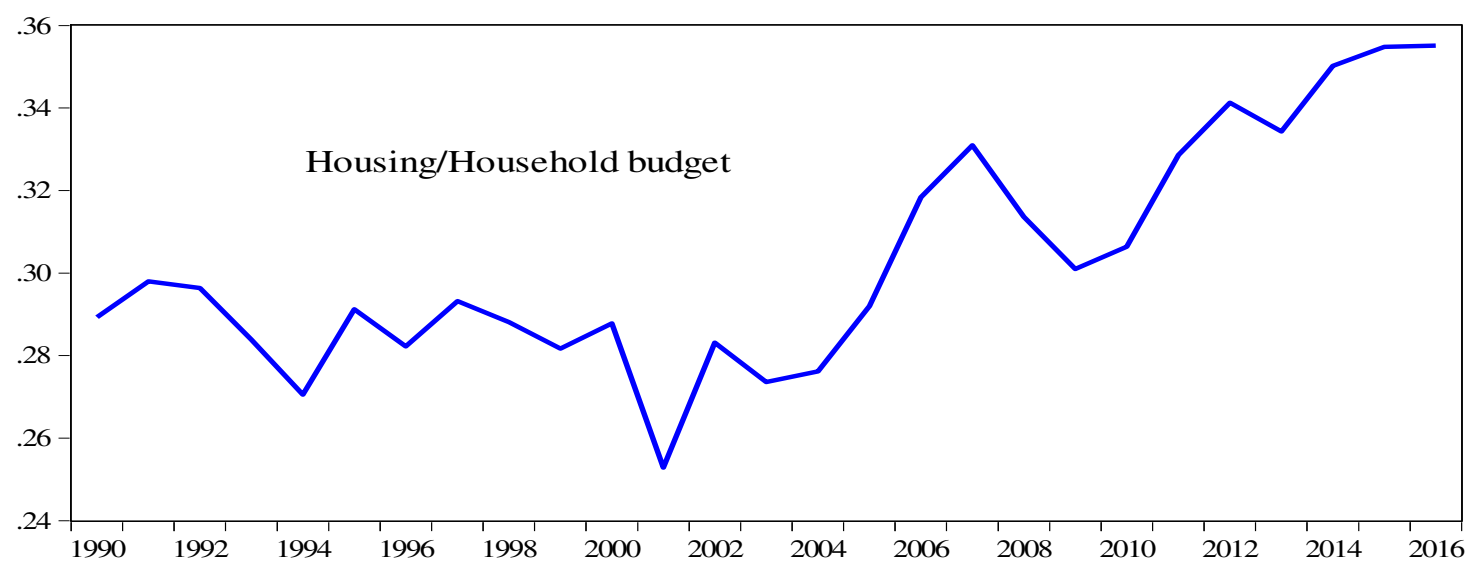

Figure 3: The share of housing in Iranian household budget without housing rent

consideration in urban area (1990 - 2016)

Source: Central Bank of Islamic Republic of Iran

It should be hastened to mention here that even the Iranian banks also direct the bank accounts of households toward housing and land section. Experts attribute the recent Iranian banks crisis to the existing stagnation in housing market (due to excessive pricing in recent years). In fact, many bank resources have been directly or indirectly injected into housing and land section.

In brief, it was discussed that the constant increase in housing and land price, which is much more than the total price index, has caused Iranian households continuously to allocate a large proportion of their incomes to housing and land section. This issue not only has increased the rate of poverty among Iranian households with lower incomes, but also it has limited production and industrial sections in Iranian economy. The question would be that whether this economic behavior is rooted in households' savings and its promotion in Iranian economy. Hence, besides examining the impacts of saving on economic growth, this question also leads the current study for statistical investigation.

\section{3. methodology}

Since the required data were available in Iranian macroeconomics with annual frequency, Johansen-Julius cointegration method and VECM approach were used to examine the relationships between the variables. Johansson-Juselius' cointegration method was used to examine the long-term relationship between these variables. Cointegration elaborates on the existence of a long-term equilibrium relationship toward which the economic system moves over the time. Frameworks such as, Engle and Granger and Engle and Yoo models could also be possibly used to investigate Cointegration. However, Johansen Juselius method is an 
appropriate method to determine long-term equilibrium relationships between two or more variables (Enders, 1995). This model is based on vector autoregressive (VAR) in which maximum likelihood determines the number of cointegration. A VAR model, which consists of an endogenous variable and $\mathrm{k}$ time lag for each variable, is represented as follows:

$$
y_{t}=A_{0}+\sum_{j=1}^{k} A_{j} y_{t-j}+\varepsilon_{t}
$$

where $A_{0}$ is the vector $n \times 1$ of the constant coefficients, $y_{t}$ is the vector $n \times 1$ of model variables, $A_{j}$ is the matrix of $n \times n$ for coefficients of the model, and vector $\varepsilon_{t}$ is the distorted statements. This equation can be written in the form of Vector Error Correction Model (VECM) as:

$$
\Delta y_{t}=A_{0}+\sum_{j=1}^{k-1} \delta_{j} \Delta y_{t-j}+\varphi y_{t-k} \varepsilon_{t}
$$

where, $\Delta$ is the first order difference and $\delta_{j}$ and $\varphi$ matrixes are equal to:

$$
\begin{gathered}
\delta_{j}=-\gamma+\sum_{j=1}^{k-1} A_{j} \\
\varphi=-\gamma+\sum_{j=1}^{k} A_{j}
\end{gathered}
$$

where matrix $\varphi$ involves information on long-term equilibrium relationships. $\alpha$ in $\varphi=\alpha \beta^{\prime}$ is the adjustment coefficient of imbalance and indicates the adjustment rate toward long-term equilibrium; $\beta$ is the matrix for long-term equilibrium correlation coefficients. JohansenJuselius maximum likelihood method determines the long-term equilibrium relationships between the variables using the statistics of Trace $\left(\lambda_{\text {Trace }}\right)$ and max-Eigen $\left(\lambda_{\text {Max }}\right)$.

\section{Data and results}

Data were obtained from time series information Central Bank of Iran(CBI) as well as World Development Indicators (WDI) published annually from 1970-2016.

\subsection{Saving and economic growth}

This study is guided by two main research questions: (1) what is the impact of saving on economic growth in Iranian economy? According to economic growth theories, does increase in saving level boost Iranian economy? Given the first question, if the saving does not lead into economic growth in Iran, (2) what is the main position of saving in Iran's economy? Is still Richard Benedick's conclusion verified in Iranian economy? Benedick (1961) argued that land and housing market was a serious rival for industrial section in Iranian economy. To answer the first research questions, the following statistical procedure is used to estimate the model :

$$
L G D P=f(L S, L F C I, P G, L G S)
$$


where, LGDP, the natural logarithm of Gross Domestic Production per capita, as an explanatory variable, was considered to represent the total economic situation. LS is the natural logarithm of Gross Domestic Saving. In Iranian economy, saving level has been always increasing. This growth has been considerably jumped after Iran-Iraq War (i.e., during the past three decades). LFCI represents the natural logarithm of fixed capital formation. PG is population growth and LGS indicates the natural logarithm of government size. Figure 4 indicates the trends of the explained variables.
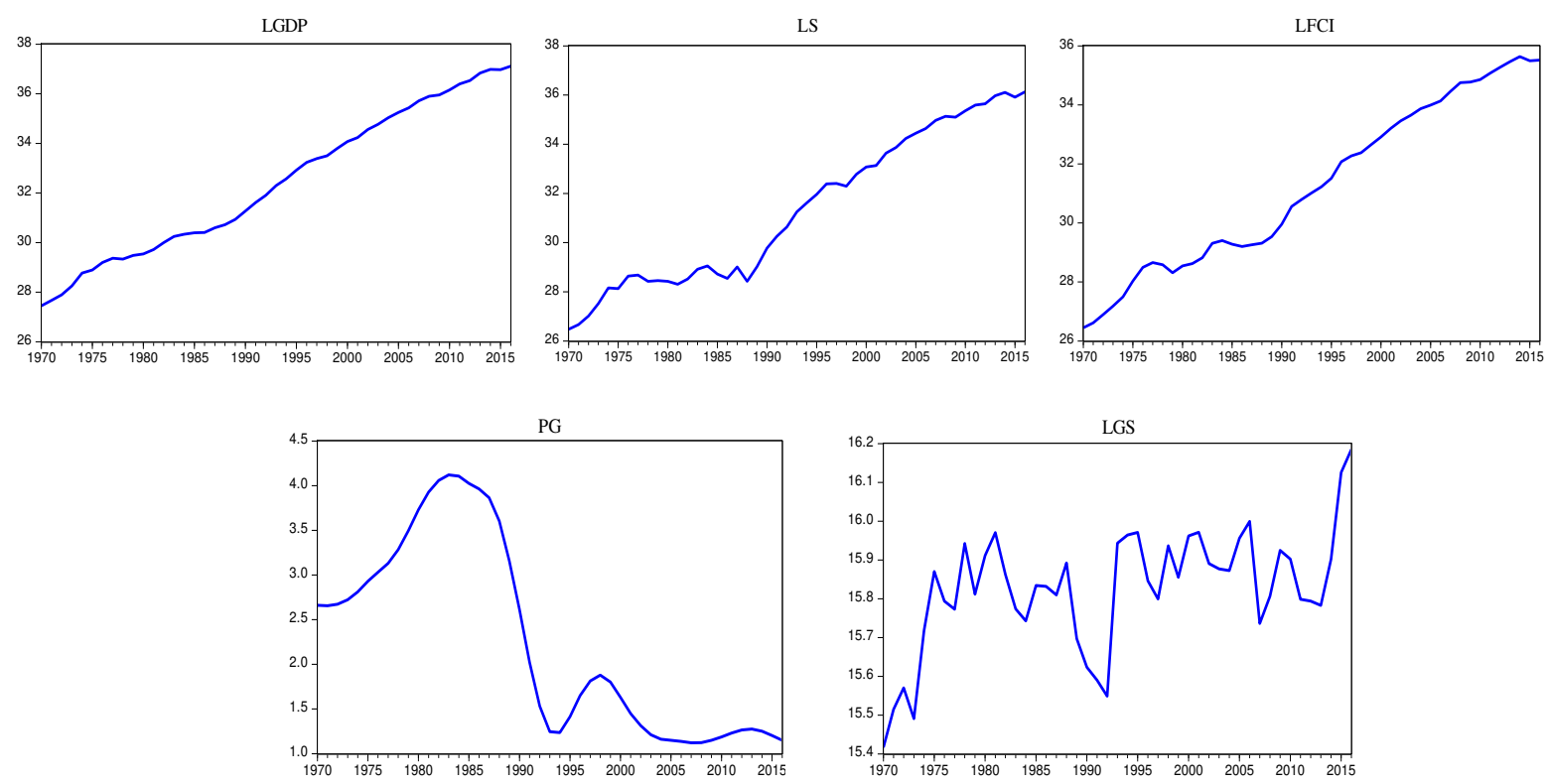

Figure 4: Time series trend of the variables (1970 - 2016)

Before the analysis of the models in time series data, the stationary state of the variables was investigated. Hence, the data were tested and explored in terms of the stationary state. To this end, Augment Dickey-Fuller (ADF) unit root test as well as Kwiatkowski-Philips -Schmidt - Shin (KPSS) test, in two states of with intercept and without trend and with intercept and trend were applied, was used to investigate the hypothesis (i.e., the presence or absence of a unit root in time series). Furthermore, many studies show that if the time series includes structural variations, the results of unit root tests such as, ADF and KPSS tests, will probably be wrong. Monte Carlo's simulations have demonstrated that if the structural break exists in the trend of one variable, the application of common unit root tests, in which it is not possible to incorporate the structural break; will violate the null hypothesis to substantiate the absence of unit root. In other words, if a variable has a structural break and at the same time is stationary, unit root tests, which do not consider the structural break, may indicate the 
variable as non-stationary and, thereby, contribute into wrong decisions. Therefore, this study employed Zivot and Andrews's unit root test to consolidate the stationary results. This test incorporated the structural break. Nevertheless, Table 1 indicates that - either with or without the inclusion of structural break - the results of the unit root tests showed that all variables had the first order of integration.

Table 1: Unit root tests

\begin{tabular}{cccccc}
\hline & LGDP & LS & LFCI & PG & LGS \\
ADF (c) & -0.63 & -0.38 & -0.96 & -1.23 & -2.49 \\
ADF(ct) & -1.79 & -1.51 & -2.45 & -2.92 & -2.93 \\
KPSS(c) & 0.89 & 0.87 & 0.88 & 0.63 & 0.55 \\
KPSS(ct) & $0.12^{* *}$ & $0.13^{* * *}$ & $0.10^{* * *}$ & $0.10^{* * *}$ & $0.07^{* * *}$ \\
ZA(c) & -3.18 & -3.66 & -3.78 & -4.87 & -4.00 \\
ZA(ct) & -2.42 & -4.01 & -3.73 & -4.89 & -4.12 \\
\hline Statistics with first difference & $\Delta$ LGDP & $\Delta$ LS & $\Delta$ LFCI & $\Delta$ PG & $\Delta$ LGS \\
\hline ADF (c) & $-4.70^{* * *}$ & $-5.98^{* * *}$ & $-4.00^{* * * *}$ & $-5.41^{* * *}$ & $-7.01^{* * * *}$ \\
ADF(ct) & $-4.68^{* * *}$ & $-5.91^{* * *}$ & $-4.02^{* * *}$ & $-5.40^{* * *}$ & $-6.93^{* * * *}$ \\
KPSS(c) & $0.10^{* * *}$ & $0.08^{* * *}$ & $0.16^{* * *}$ & $0.13^{* * *}$ & $0.12^{* * *}$ \\
KPSS(ct) & $0.09^{* * *}$ & $0.08^{* * *}$ & $0.14^{* *}$ & $0.11^{* * * *}$ & $0.11^{* * *}$ \\
ZA(c) & $-6.24^{* * *}$ & $-6.10^{* * * *}$ & $-5.88^{* * * *}$ & $-8.68^{* * *}$ & $-6.14^{* * *}$ \\
ZA(ct) & $-6.30^{* * *}$ & $-6.11^{* * *}$ & $-6.07^{* * *}$ & $-9.63^{* * *}$ & $--6.42^{* * *}$ \\
\hline Order of Integration & $\mathrm{I}(1)$ & $\mathrm{I}(1)$ & $\mathrm{I}(1)$ & $\mathrm{I}(1)$ & $\mathrm{I}(1)$ \\
\hline
\end{tabular}

Notes: (i) c, denotes statistics with a constant; ct is the statistics with a constant and linear trend.

(ii) $\Delta$ represents the first difference.

$* * *$ denotes significant level at $1 \%$.

$* *$ denotes significant level at $5 \%$.

*denotes significant level at $10 \%$.

After investigating both the unit root tests and the degree of integration variables, analyzing cointegration was in order. To this end, optimal lag length was required for cointegration analyses. It should be mentioned the degree of freedom could be severely decreased due to the small sample size as well as the presence of high number of lag. Hence, lag 3 was chosen based on the optimized lag selection criteria in Schwarz and Hannan-Queen model.

Then, after determining the optimal lag and variables' degree of integration, Johansen Juselius method was used to investigate the long-term relationship between the variables. To this end, two statistics of max-Eigen $\left(\lambda_{\text {Trace }}\right)$ and trace $\left(\lambda_{\text {Max }}\right)$ were employed. Table 2 shows the results of these tests. As the results of the trace and max-Eigen statistics confirm the presence of at least one cointegration vector at the error level of 1 percent.

Table 2 Johansen and Juselius cointegration test 


\begin{tabular}{|c|c|c|c|c|c|}
\hline $\begin{array}{c}\text { No. of } \\
\text { Cointegration } \\
\text { (Null hypothesis) }\end{array}$ & Eigenvalue & $\begin{array}{c}\text { Trace } \\
\text { statistics }\end{array}$ & $\begin{array}{l}\text { Critical } \\
\text { value } \\
\text { (Trace) }\end{array}$ & $\begin{array}{c}\text { Max- } \\
\text { Eigen } \\
\text { Statistics }\end{array}$ & $\begin{array}{c}\text { Critical } \\
\text { value(Max- } \\
\text { Eigen Statistics) }\end{array}$ \\
\hline$r=0$ & 0.69 & $\begin{array}{c}100.13 * \\
{[0.00]}\end{array}$ & 69.81 & $\begin{array}{l}50.69 * \\
{[0.00]}\end{array}$ & 33.87 \\
\hline $\mathrm{r} \leq 1$ & 0.44 & $\begin{array}{l}49.43 \\
{[0.03]}\end{array}$ & 47.85 & $\begin{array}{l}25.57 \\
{[0.08]}\end{array}$ & 27.58 \\
\hline $\mathrm{r} \leq 2$ & 0.27 & $\begin{array}{l}23.86 \\
{[0.20]}\end{array}$ & 29.79 & $\begin{array}{l}13.71 \\
{[0.38]}\end{array}$ & 21.13 \\
\hline$r \leq 3$ & 0.13 & $\begin{array}{l}10.14 \\
{[0.26]}\end{array}$ & 15.49 & $\begin{array}{c}6.05 \\
{[0.60]}\end{array}$ & 14.26 \\
\hline
\end{tabular}

Note: The numbers in brackets indicate p-values.

*denotes significant level at $1 \%$.

This section deals with the long-term relationships of the model. Table 3 indicates the results of VECM estimation. Results show that the increase in saving level has negatively impacted on Iranian economic growth in long-term. Hence, based on the long-term cointegration estimation, the observational evidence related to Figure 1 is also verified. It seems that saving is not considered as significant in Iranian economy and, thereby, it does not lead into generative investment. From this perspective, investigating the structure of saving would be highly significant to understand Iranian economy. Table 3 also illustrates that population growth has negative impacts on Iranian economic growth in long-term. Researches show that the lack of coordination between population growth and economic facilities challenges economic development in developing countries. Of course, in many economic growth models, population growth is considered as a hindrance to increase of income per capita. The government size has also negatively influenced the Iranian economic growth. According to theoretical considerations, hence, it seems that not only the public sector is inefficient in Iranian economy, but also it challenges the private sector to function appropriately, particularly by its complicated rules, sophisticated bureaucracies, and serious interventions. At last, based on theoretical considerations, LFCI has positive impacts on economic growth. Moreover, the amount of error correction model is significant indicating that economic growth is not remarkable in short-term, however, it could potentially create long-term relationships between the variables in the models.

Table 3 VECM results for LGDP

\begin{tabular}{cccc}
\hline & Coefficient & Std.error & t-statistics \\
\hline Constant & -244.82 & - & - \\
LS & -7.30 & 1.56 & -4.66 \\
LFCI & 8.26 & 1.61 & 5.13 \\
PG & -2.76 & 0.50 & -5.50 \\
LGS & -14.88 & 2.27 & -6.54 \\
ECM(-1) & -0.095 & 0.017 & -3.38 \\
\hline
\end{tabular}


For robust results, we used the impulse response function. Impulse response functions describe the dynamic behavior of variables in linear equations as a function of time and also in response to one standard deviation shock. Furthermore, the impulse response functions can effectively analyze the dynamic behavior between the variables of a system in a long-term.

To this end, Figure 5 indicates the results of Impulse response functions obtained for dependent economic growth model. These findings confirm the results of estimation in VECM model; so that, a shock which is mounted to one standard deviation on saving has a negative impact on Iran's economic growth.
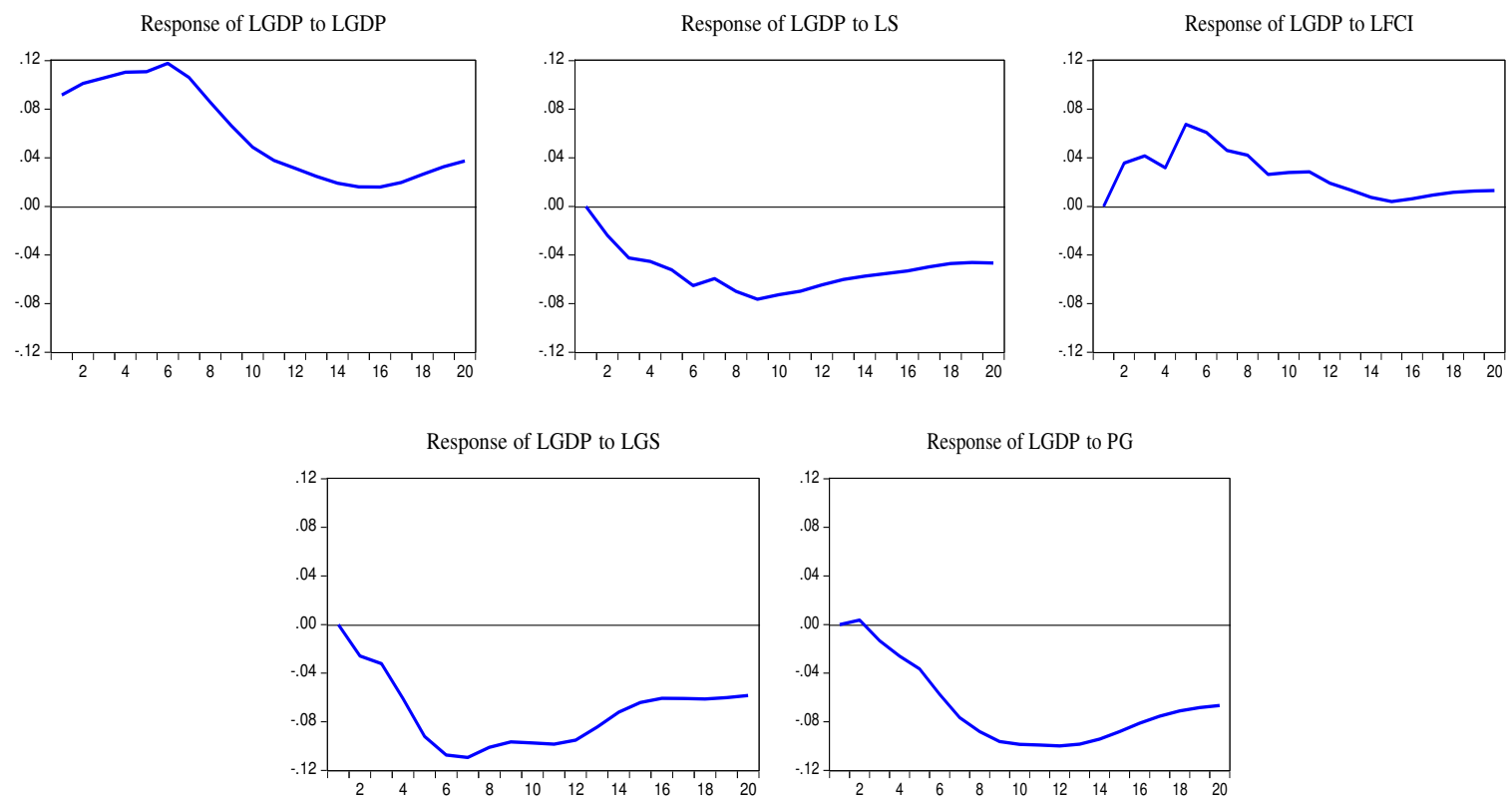

Figure 5: Impulse response function for dependent variable LGDP

The second research question is as follow: what is the nature of saving in Iranian economy and where the saving is directed to? As it was mentioned earlier, land and housing are traditionally considered as the most expensive and significant properties for Iranian families. In Iranian community, buying houses and lands is viewed as a most important speculation choice; hence, it would be possible to discuss the nature of saving in Iranian economy with respect to this tendency among Iranian households .

On the other hand, as it was shown in figure 2, in comparison to other sections, land and housing market has experienced a high rate of inflation during the recent years, and it includes a large proportion of Iranian households' budget having harmful consequences on Iranian economy. Is the cause of this condition due to the flow of saving to housing and land market? In order to answer this question, two models with various dependent variables are used to accurately measure; the impact of savings on housing price index and also, the 
difference between housing and land price index and the total price index as another dependent variable are examined.

\subsection{Saving and housing}

This paper hypothesizes that there are some factors direct the saving to land and housing market in Iranian economy including weak property rights, the lack of competitive industry, and traditional economic insecurity. These factors induce people to invest in land and housing section since it is the most convenient and effective strategy for protecting the value of money, particularly when the people classically know that there is a continuous rise in price levels. Therefore, another VECM model was used in order to examine this hypothesis. The purpose of this model is to investigate the impact of saving on housing price index; as a matter of course, a further complementary model is utilized to examine the effect of saving rate on the difference observed between housing price index and total price index. Hence, the following models are used:

$$
\begin{aligned}
& L H P=f(L S, L G D P, P G, M G) \\
& D i f f P=f(L S, L G D P, P G, M G)
\end{aligned}
$$

where, LHP represents the total price index having continuously been increased during the recent years. LS show the natural logarithm of saving, and LGPD indicates natural logarithm of Gross Domestic Product. PG indicates population growth which can theoretically elaborate on the rise in house prices; however, it should be pointed out that population growth has recently decreased in Iranian society (see Figure 4). Therefore, this index may not be proposed as the most significant factor contributing to the growth of price index in housing section. MG shows money (liquidity) growth, which is theoretically considered as an important factor making fluctuations in price indexes. The excess of liquidity growth has always been the main serious challenge for the growth of the economy in Iran. Furthermore, its direction to productive investment is a major problem for Iranian policymakers. Due to previous economic trends as well as the social and cultural structures, housing section has always been subjected to absorption of wandering liquidities in the Iranian economy. It is worth mentioning that banks and financial institutions offer large amounts of the loans to people managing business in housing and land markets. And finally; DiffP is the difference between housing price index and the total price index.

Since housing price index has preceded the total price index, this study has investigated the difference exist between the total price index and housing price index to clearly show and 
examine the effect of saving on the most significant section of families' budget. Figure 2 indicated the trend of price growth of housing being compared to total price index. Figure 4 showed the data for PG, LGDP, and LS. Therefore, only the trend of LHP and MG variables remains that illustrates in Figure 6.
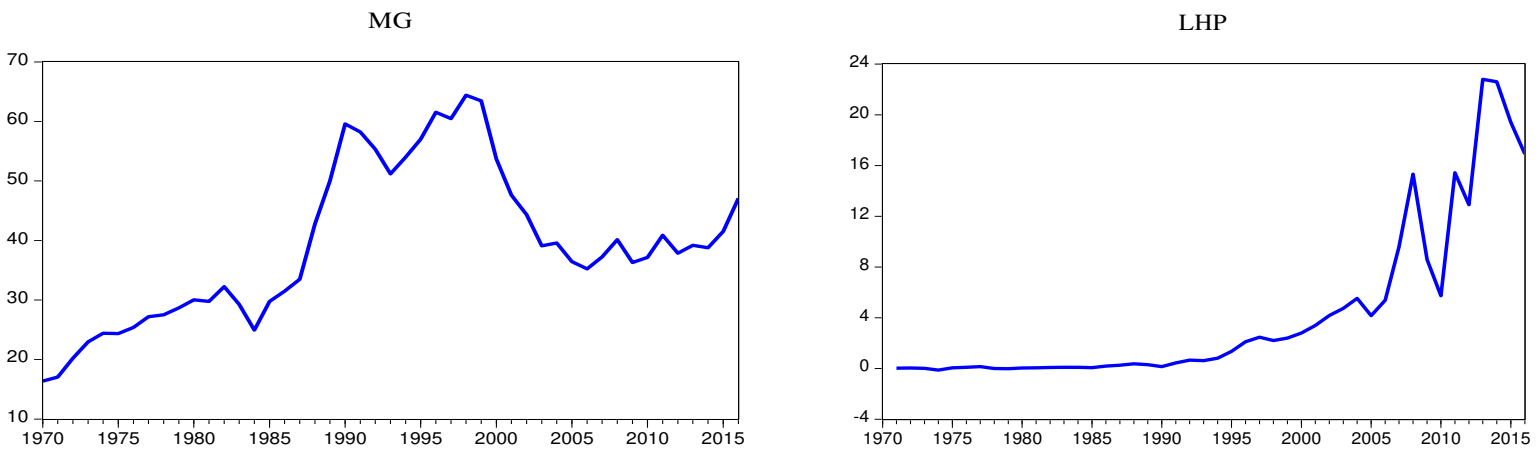

Figure 6: the trends of MG and LHP in period of 1970- 2016.

Now, the unit root test feature of the variable is examined. The results of unit tests show that all the variables both in the tests with structural break and those without structural breaks are integrated of first level.

Table 4: Unit root tests

\begin{tabular}{ccccccc}
\hline & LHP & LS & LGDP & PG & MG & DiffP \\
\hline ADF (c) & -0.27 & -0.38 & -0.63 & -1.23 & -1.98 & -2.52 \\
ADF(ct) & -1.94 & -1.51 & -1.79 & -2.92 & -1.94 & -2.64 \\
KPSS(c) & 0.92 & 0.87 & 0.89 & 0.63 & $0.39^{* *}$ & 0.57 \\
KPSS(ct) & 0.26 & $0.13^{* *}$ & $0.12^{* *}$ & $0.10^{* * *}$ & 0.17 & 0.12 \\
ZA(c) & -4.33 & -3.66 & -3.18 & -4.87 & -4.34 & -4.05 \\
ZA(ct) & -2.76 & -4.01 & -2.42 & -4.89 & -4.01 & -4.59 \\
\hline Statistics with first difference & $\Delta$ LHP & $\Delta$ LS & $\Delta$ LGDP & $\Delta$ PG & $\Delta$ MG & $\Delta$ DiffP \\
\hline ADF (c) & $-5.88^{* * *}$ & $-5.98^{* * *}$ & $-4.70^{* * *}$ & $-5.41^{* * *}$ & $-4.22^{* * *}$ & $-6.01^{* * *}$ \\
ADF(ct) & $-6.18^{* * *}$ & $-5.91^{* * *}$ & $-4.68^{* * *}$ & $-5.40^{* * *}$ & $-4.20^{* * *}$ & $-5.93^{* *}$ \\
KPSS(c) & $0.19^{* * *}$ & $0.08^{* * *}$ & $0.10^{* * *}$ & $0.13^{* * *}$ & $0.16^{* * *}$ & $0.12^{* * *}$ \\
KPSS(ct) & $0.04^{* * *}$ & $0.08^{* * *}$ & $0.09^{* * *}$ & $0.11^{* * *}$ & $0.07^{* * *}$ & $0.09^{* * *}$ \\
ZA(c) & $-6.32^{* * * *}$ & $-6.10^{* * *}$ & $-6.24^{* * *}$ & $-8.68^{* * *}$ & $-4.94^{* *}$ & $-5.95^{* * *}$ \\
ZA(ct) & $-6.26^{* * *}$ & $-6.11^{* * *}$ & $-6.30^{* * *}$ & $-9.63^{* * *}$ & $-5.60^{* * *}$ & $-5.87^{* * *}$ \\
\hline Order of Integration & $\mathrm{I}(1)$ & $\mathrm{I}(1)$ & $\mathrm{I}(1)$ & $\mathrm{I}(1)$ & $\mathrm{I}(1)$ & $\mathrm{I}(1)$ \\
\hline
\end{tabular}

Notes: (i) c, denotes statistics with a constant; ct is the statistics with a constant and linear trend.

(ii) $\Delta$ represents the first difference.

$* * *$ denotes significant level at $1 \%$.

$* *$ denotes significant level at $5 \%$.

$*$ denotes significant level at $10 \%$.

After the investigation of unit root tests of variables and the specification order of integration of variables, the co-integrated analyses were examined. First, we need to determine the optimal lag degrees. Hence, lag 2 was selected for two models of dependent LHP as well as the dependent variable of DiffP. Afterward, Johansen-Julius method was applied to 
investigate the long-term relationships observed between the variables of the models. Table 5 shows the obtained results.

Table 5 Johansen and Juselius cointegration test

\begin{tabular}{|c|c|c|c|c|c|}
\hline $\begin{array}{c}\text { No. of } \\
\text { Cointegration } \\
\text { (Null hypothesis) }\end{array}$ & Eigenvalue & $\begin{array}{c}\text { Trace } \\
\text { statistics }\end{array}$ & $\begin{array}{c}\text { Critical } \\
\text { value } \\
\text { (Trace) }\end{array}$ & $\begin{array}{c}\text { Max- } \\
\text { Eigen } \\
\text { Statistics } \\
\end{array}$ & $\begin{array}{c}\text { Critical } \\
\text { value(Max- } \\
\text { Eigen Statistics) }\end{array}$ \\
\hline \multicolumn{6}{|c|}{ Dependent variable: LHP } \\
\hline$r=0$ & 0.66 & $\begin{array}{c}107.26^{*} \\
{[0.00]}\end{array}$ & 69.81 & $\begin{array}{l}46.53^{*} \\
{[0.00]}\end{array}$ & 33.87 \\
\hline $\mathrm{r} \leq 1$ & 0.54 & $\begin{array}{l}60.73^{*} \\
{[0.00]}\end{array}$ & 47.85 & $\begin{array}{l}34.18^{*} \\
{[0.00]}\end{array}$ & 27.58 \\
\hline$r \leq 2$ & 0.28 & $\begin{array}{l}26.55 \\
{[0.11]}\end{array}$ & 29.79 & $\begin{array}{l}14.23 \\
{[0.34]}\end{array}$ & 21.13 \\
\hline \multicolumn{6}{|c|}{ Dependent variable: DiffP } \\
\hline $\mathrm{r}=0$ & 0.78 & $\begin{array}{c}116.21^{*} \\
{[0.00]}\end{array}$ & 69.81 & $\begin{array}{l}66.49^{*} \\
{[0.00]}\end{array}$ & 33.87 \\
\hline $\mathrm{r} \leq 1$ & 0.44 & $\begin{array}{l}49.71 \\
{[0.03]}\end{array}$ & 47.85 & $\begin{array}{l}25.30 \\
{[0.09]}\end{array}$ & 27.58 \\
\hline$r \leq 2$ & 0.22 & $\begin{array}{l}24.40 \\
{[0.18]}\end{array}$ & 29.79 & $\begin{array}{l}10.92 \\
{[0.65]}\end{array}$ & 21.13 \\
\hline
\end{tabular}

Note: The numbers in brackets indicate p-values.

*denotes significant level at $1 \%$.

The results of the Johansen-Julius test for both models indicates presence of at least one cointegration vector in both models was confirmed at $1 \%$ error level.

This section deals with the long-term relationships of the model. Table 6 indicates the results of VECM estimation.

Table 6 VECM results for dependent variables LHP and DiffP

\begin{tabular}{cccc}
\hline & Coefficient & Std.error & t-statistics \\
\hline \multicolumn{2}{l}{ Dependent variable: LHP } & & \\
\hline Constant & 448.64 & - & - \\
LS & 5.06 & 0.57 & 8.74 \\
LGDP & 29.01 & 4.45 & 6.51 \\
PG & 11.81 & 1.96 & 6.02 \\
MG & 0.41 & 0.08 & 4.64 \\
ECM(-1) & -0.51 & 0.26 & -2.02 \\
\hline Dependent variable: DiffP & & \\
\hline Constant & 1669.14 & - & - \\
LS & 253.43 & 50.20 & 5.04 \\
LGDP & -203.36 & 44.56 & -4.56 \\
PG & 131.16 & 26.63 & 4.92 \\
MG & 0.92 & 0.59 & 1.56 \\
ECM(-1) & -0.88 & 019 & -4.48 \\
\hline
\end{tabular}

This section deals with the long-term relationships of the model. Table 6 indicates the results of VECM estimation. According to the results, in long-term, LS has a positively significant effect on both LHP and DiffP variables. Comparing the coefficients, especially in DiffP model, it could be stated that saving has had the highest impact on the existing difference between housing price index and the total price index. Speculation activities and increase in 
future prices are probably the main reasons, which motivate Iranian households to direct the savings toward housing and land market. Therefore, due to the Iranian economic structure, savings usually lead to permanent block in housing market rather than flowing to industry section. This is in line with Richard Benedick's (1961) claim that housing section is a serious rival for industry section in Iranian economy. In fact, this phenomenon shows the structure of savings in the economy of Iran.

The impact of LDGP is significant since the increase in the amount of Gross domestic product has increased the LHP but, increase in LGDP caused reduces in DiffP. Population growth also has contributed to the sudden increase of housing price index in Iranian economy. In addition, money growth also leads into increase housing price index in longterm. Thus, it can be concluded that liquidities also move to housing and land section in the economy of Iran. As it was mentioned earlier, the liquidity direction is carried out, not only by the ordinary people, but also by the banks and financial institutions. Since 2005, when the presence of Iranian private financial institutions sharply increased, housing price index has grown far more than the total price index in Iranian economy. Hence, it might be claimed that Iranian financial institutions have flown most of their resources toward this market.

The amount coefficient of error correction model (ECM) is shown in Table 6. ECM is an indicator of the rate of error correction and the tendency to long-term equilibrium. This coefficient demonstrates that how much the imbalance of the dependent variable has adjusted in each period and moved toward the long-term relation. In this respect, the results of VECM approach shows that the amount of ECM is -0.51 in the LHP dependent model and -0.88 for variable in the DiffP dependent model. These amounts are significant indicating that, in long run, the housing section corrects itself so that it can establish the long-term relationship among the variables in the models.

Furthermore, Figure 7 shows the results of impulse response functions in each independent LHP and DiffP models. According to these figures, an exerted shock, which is amounted to one standard deviation, has positive impact both on LHP and DiffP. Therefore, the results indicate that saving is directed toward land and housing market in Iranian economy. 

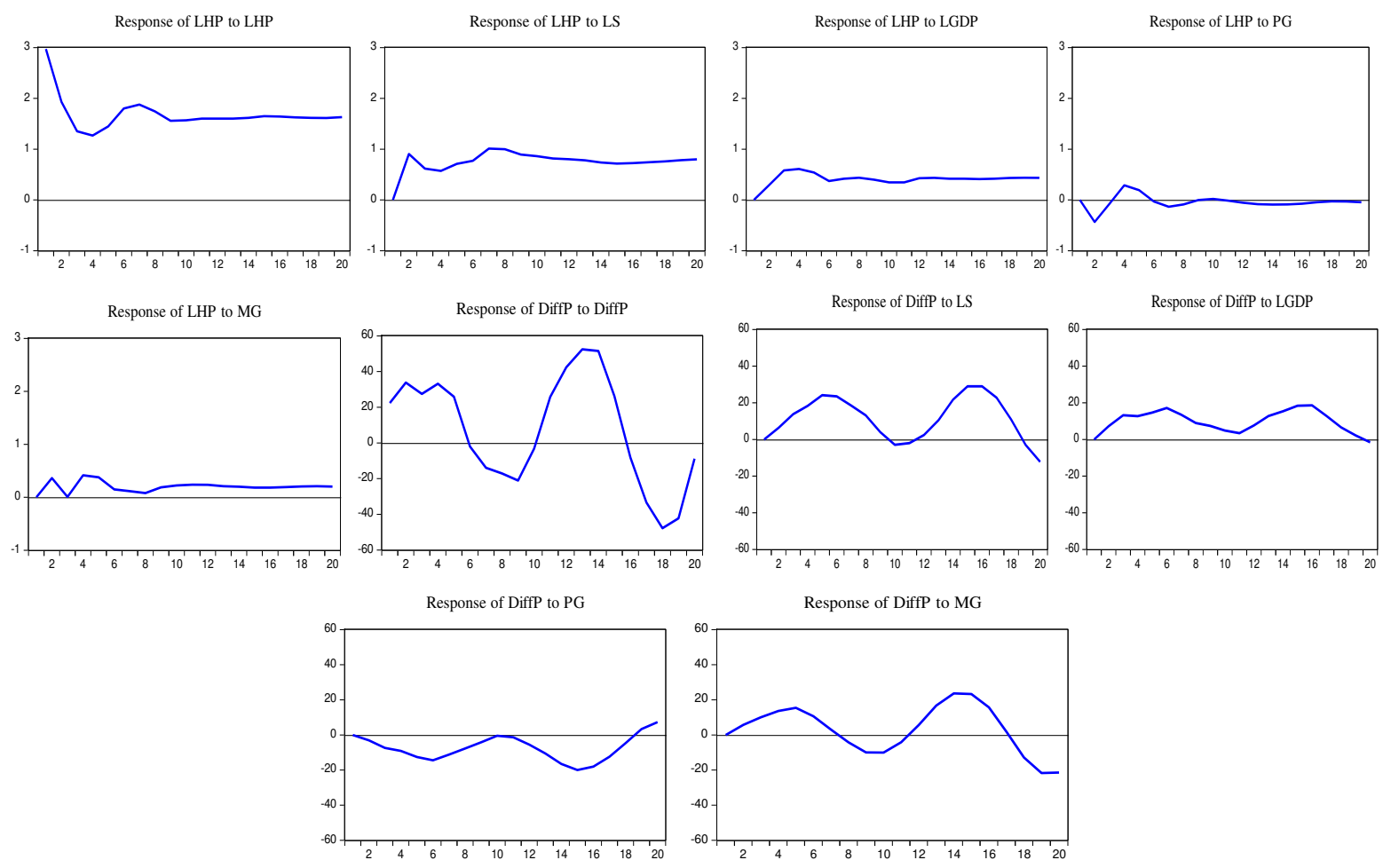

Figure 7: Impulse response function for dependent variables LHP and DiffP

\section{Discussion}

As it was mentioned in introduction section, according to the theories of macroeconomics, economic development as well as growth models, it is expected that saving in Iran same as other countries could contribute into high economic growth since it increases the levels of investment and capital formation.

Although economic theories mostly focus on optimal level of saving and its impact on economy, little attention has been drawn on nature and the structure of saving. The structure and nature of saving is of great significance, particularly, for countries experiencing low levels of investment and economic growth despite their possible high saving rate.

In order to confirm this argument, one VECM model was used to investigate the relationship between saving and economic growth in long-term in Iranian economy. The results indicated that rises in saving rate has negative impact on Iranian economic growth. Hence, unlike the conventional economic theories elaborating of saving, the saving has not been considered as a productive source for investment in Iran. Instead, it has been functioned as a hindrance to economic growth in Iranian economy.

It seems that if we want that the economic theories - from circular of income to economic development model, which deal with the rise in saving rate - have desirable impacts on economic growth, we need to investigate the nature of saving, the financial structure, 
industry's structure, the private sector's capabilities, the community's available facilities, and money circle manner. If the economic structure can't absorb the savings, it may not be expected that saving can be converted into productive investment; hence, the economic leakage -injection circular might not function appropriately causing instabilities in economy. If the saving leads into the investment, it will increase the income and salaries contributing into welfare among the public community. However, if the saving be directed toward land and housing market or gold and currency section (motivated by speculation activities), considering that consumption has declined and firms' incomes are limited, but this leakage has not entered the economy as a productive investment, and not only directly limited income of agencies, but also indirectly, by disrupting the economic order, such as the devaluation of the national currency, will cause other major problems that reduce economic growth. Hence, pay attention to nature of saving is very essential in each economy.

This economic behavior not only reflects people's view to Iranian economic instability, but also it has become a common economic practice among Iranian households. Most of Iranian households keep and convert their whole life savings into properties. These estates are interpreted as the symbols of someone's success and, they are usually inherited to their siblings.

The phenomenon of empty houses is evident in Iranian economy. According to the reports of Iran Central Bank as well as Iran's Ministry of Economy, the number of vacant residential units increased from 633000 (in 2005) to 1.6 (in 2010) and 2.6 million units (in 2015). This increase rate shows that the average annual growth of vacant units was $17 \%$ across the country during the years of 2005 - 2015. Many people by different occupations invest their extra savings on land and housing market. They always benefit from this economic behavior since it is a collective behavior and resulted in supply limitations. Hence, due to this action, land and housing index is reached to its highest point in comparison to the total prices index. The consequences of such a behavior were described in the beginning section of the paper. This economic behavior has resulted in serious damages to Iran's environment. That is, many Iranian jungles and natural lands have been destructed at the expanse of constructing expensive houses and villas on which. Furthermore, this behavior has encouraged people to segment a lot of farmlands for the purpose of home construction, dramatically decreasing the productivity in Iranian agricultural section.

In addition, some of the consequences of this economic behavior are as follows: an increase in land price (as a fixed capital for business which has caused serious limitation on the onset of business in Iran), the flow of financial resources toward land and housing and lack of these 
resources in industry section, allocation of a large proportion of households budget to supply housing and thus huge consumption limitation of other goods, wasting lifetime on supplying the housing, integration of the banking system's success to continuous inflation growth in land and housing section, and etc.

However, the most significant consequence of savings' change to housing and land is probably the severe inequality found among Iranian households. Unfortunately, Gini index or other income-based indexes are generally used to estimate the economic inequality. Real wages are usually decreased in constant inflation, but official wages are only observable in lack of transparency situation. Therefore, it can be claimed that it would be misleading to estimate the economic inequality in Iranian economy by Gini index. As it was mentioned previously, due to major jump in housing and land prices, it may take decades to buy a house in Iran. Hence everyone who buys a house soon is the winner. Many students, who continue their education at the university level and enter the labor market at a later stage, may never be able to reach the level of welfare of those students with lower level of education started to work and bought their properties earlier. This issue has drastically decreased the value and importance of education in Iran. Therefore, the continuous increase in housing and land price as well as the recurrent decline in real wages has contributed into severe inequality among Iranian households bringing about unfavorable consequences in Iranian community.

Of course, another part of the saving structure, which has not been focused on in this study, is the speculative flow of savings toward foreign exchange and gold markets. Since the high inflations persistently exist in Iranian economy, people continually attempt to exchange their national currency to foreign exchanges and precious metals. In economic turbulences, this behavior has been occurred more severely causing serious shocks to the economy. The constant decline in national money value has been a serious obstacle preventing the foreign capitals to find their ways into the Iranian economy. Hence, this phenomenon has weakened Iranian economic infrastructures in terms of intelligent capital, technology, and knowledge.

These economic shocks also bring about social and cultural consequences. In addition to the increase of short-term view and decline of ethics which are associated with the nature of speculation, people become depressed and disappointed due to worries about the decrease in the value of their wage and property. Accordingly, it harms the endeavor and work culture in Iranian community in general.

Therefore, the structure of saving in Iranian economy has become a serious obstacle against economic growth and development through expanding unproductive section, speculation behaviors, extensive speculation revenues, and broking and also developing instability in the 
society. Thereby, it seems that discussion on the structure of saving would be more important than its amount in the Iranian economy.

\section{Conclusion}

This study challenged the argument that saving could lead to investment and economic growth in the economy of Iran. Investigation of variables trend and estimation of a long-term model in the Iranian economy revealed that an increase in saving did not result in economic growth in Iranian economy. On the other hand, past decades document an increase in the rate of housing and land price index even far more than the total price index so that a large amount of saving has led to this section and this has constantly caused a growth leap in the price, which has changed the individuals' economic behaviors in the economy of Iran.

In this investigation, considering the nature of data, first, the VECM approach was used to examine the long-term effects of saving on economic growth; then, the study investigated the long-term relationship between the saving and housing price index (LHP) and the difference between the land and housing price index from the total price index (DiffP). The results showed that the saving did not lead to economic growth, but it had motivated the speculation activities reducing the economic growth in long-term in Iranian community. Hence, the findings indicate that saving has positive impact both on LHP and DiffP. In other words, the savings have been directed into the land and housing section increasing the price indexes in this market in comparison to other sections. To sum up, saving, liquidity growth and population have remarkably increased LHP as well as DiffP.

Housing market has attracted a high level of financial resources, since the Iranian industrial section fails to absorb a high level of liquidity, and people are skeptical to invest in this section as well. This trend has been changed to a long-term economic behavior among Iranian people, which functions as an obstacle to economic reform in Iran. This behavior has changed the structure of Iranian economy in such a manner that it may not be possible to improve it in short-term effects of reform. Many individuals have been mentally used to inject their savings and incomes into speculative transactions. In addition, several occupations have been created around this structure; non-interchangeable economy has been extended; production section has not developed and thus it is not potential to absorb saving. All these factors have generally created a structure which is too hard to exit from. Tax structure reform has not practically been effective to improve this situation in recent years. As a result, economic cycle has been harmed in Iranian economy, and the savings are being 
diverted from the economy as leakage. This strange phenomenon is considered as an obstacle to economic growth. Of course, the structural change in Iranian economy is encountered with many other major obstacles as well.

Thus, economic improvement and investment growth could not be expected in Iranian economy without practicing any reform on its saving structure. In Iranian economy, the policy makers have traditionally focused on increasing the amount of saving not on directing it to the productive investment. For example, in some developed countries such as Germany, there are some regulations set to limit the speculation activities in land and housing markets. Such protocols have not been formulated in Iranian housing market, so, this sector has devoured a large part of savings. Therefore, it seems that the saving structure needs to be seriously reviewed and modified to limit the speculation business in Iranian land and housing market. Such a change is vital despite its much difficulty. The lack of any attempt to perform reforms on saving structure could rapidly contribute other sections of Iranian economy into stagnation, and thereby, the government needs to constantly close its borders and revitalize the domestic economy to save these economic sections. This policy, which ignores the structure of saving, has been followed in recent years resulting in an increasing debilitating recession in Iranian economy. Similar to previous years, these small steps could not be effective at all given the depth of the problem. Accordingly, in order to promote the level of Iranian economic growth, it is necessary to reform the land and housing market, withdraw savings from this section, and prevent speculative activities in this market.

The results of the research suggest that it is necessary for the developing countries such as Iran that not only focus on savings' structure in their economy, but also design a mechanism moving the savings toward productive investment. Otherwise, excessive savings could even undermine investment and economic growth. The structure of saving may become an unfavorite habit in the long run, and therefore, it may be difficult to solve the problem in a short period of time. Hence, changing the structure of savings is of great importance to Iran's economy. Given the depth of its effect on the economy, the current policies do not make it possible to get out of this situation.

It seems that the government needs to impose heavy taxes such as, capital gains tax (CGT), on additional houses (not merely on empty houses) and multiple transactions of land and houses within a year. The government also needs to implement new policies to keep the value of people's money up so that it could debilitate the speculative activities and savings block in this section. The information about the individuals' amount of wealth and ownership of their land and housing should be clear. Also, it would be effective to revise the redistribution rules 
of taxations in this regard. Considering that a significant amount of liquidities in Iranian economy is related to the banking system, the banking regulations need to be revised to restrict the liquidity toward land and housing market. Finally, Iranian economic policymakers are also required to develop a mechanism supplying housing for homeless people in Iranian economy.

\section{Declaration:}

\section{Data Availability Statement}

The data that support the findings of this study are openly available in Central Bank of Iran (CBI) https://www.cbi.ir/default_en.aspx as well as World Development Indicators (WDI) https://databank.worldbank.org/reports.aspx?source=world-development-indicators

\section{Founding:}

There are no Funding Sources.

\section{Compliance with Ethical Standards}

\section{Conflict of Interest:}

The author declares that they have no conflict of interest.

\section{Research Involving Human and Animal Participants:}

This article does not contain any studies with human participants or animals performed by any of the authors.

\section{Informed Consent:}

Informed consent was obtained from all individual participants included in the study.

\section{References}

Agrawal, P. (2001). The relation between savings and growth: Cointegration and causality evidence from Asia. Applied Economics, 33(4), 499-513.

Athukorala, P. C., \& Sen, K. (2004). The determinants of private saving in India. World Development, 32(3), 491-503.

Attanasio, O. P. (1993). A cohort analysis of saving behavior by US households (No. w4454). National Bureau of Economic Research. 
Attanasio, O. P., Picci, L., \& Scorcu, A. E. (2000). Saving, growth, and investment: A macroeconomic analysis using a panel of countries. Review of Economics and Statistics, 82(2), 182-211.

Ballinger, T. P., Hudson, E., Karkoviata, L., \& Wilcox, N. T. (2011). Saving behavior and cognitive abilities. Experimental Economics, 14(3), 349-374.

Benedick, R. E. (1964). Industrial finance in Iran. The International Executive, 6(4), 20-20.

Blanchard, O., \& Giavazzi, F. (2006). Rebalancing growth in China: A three-handed approach. China \& World Economy, 14 (4), 1-20.

Browning, M., \& Lusardi, A. (1996). Household saving: Micro theories and micro facts. Journal of Economic Literature, 34(4), 1797-1855.

Chamon, M., Liu, K., \& Prasad, E. (2013). Income uncertainty and household savings in China. Journal of Development Economics, 105, 164-177.

Chowdhury, A., \& Kirkpatrick, C. (2005). Development policy and planning: an introduction to models and techniques. London, UK: Routledge.

Dickey, D. A., \& Fuller, W. A. (1979). Distribution of the estimators for autoregressive time series with a unit root. Journal of the American Statistical Association, 74(366a), 427-431.

Disney, R., Henley, A., \& Stears, G. (2002). Housing costs, house price shocks and savings behaviour among older households in Britain. Regional Science and Urban Economics, 32(5), 607-625.

Dornbusch, R; Fischer, S \& Startz, R (2011). Macroeconomics. New York, USA: McGrawHill -Hill Higher Education.

Enders, W. (1995). Applied Econometric Time Series. New York, USA: Jhon Wielly Sons.

Engelhardt, G. V. (1996). House prices and home owner saving behavior. Regional Science and Urban Economics, 26(3-4), 313-336.

Friedman, B. M. \& Warshawsky, M. J. (1990). The cost of annuities: Implications for saving behavior and bequests. The Quarterly Journal of Economics, 105(1), 135-154.

Fry, M. J. (1980). Saving, investment, growth and the cost of financial repression. World Development, 8(4), 317-327.

Gavin M, Hausmann R, \& Talvi, E. (1997). Saving behaviour in Latin America: Overview and policy issues. In R. Hausmann \&H. Reisen (Eds). Promoting Savings in Latin America (pp. 13-43). Paris, France: Organization of Economic Cooperation and Development and Inter-America Development Bank. 
Hunt, E. K. (2003), Property and prophets: The evolution of economic institutions and ideologies ( $7^{\text {th }}$ edition). Armonk, New York, USA: Routledge.

Kwiatkowski, D., Phillips, P. C. B., Schmidt, P. \& Shin, Y. (1992). Testing the null hypothesis of stationarity against the alternative of a unit root. Journal of Econometrics, 54, 159-178.

Lusardi, A. (2008). Household saving behavior: The role of financial literacy, information, and financial education programs (No. w13824). National Bureau of Economic Research.

Mankiw, G (2010), Macroeconomics (7th edition). New York, USA: Worth Publishers.

Odhiambo, N. M. (2009). Savings and economic growth in South Africa: A multivariate causality test. Journal of Policy Modeling, 31(5), 708-718.

Ogaki, M., Ostry, J. D., \& Reinhart, C. M. (1996). Saving behavior in low-and middleincome developing countries: A comparison. Staff Papers, 43(1), 38-71.

Romer, D. (2012). Advanced macroeconomics (4th edition). New York, USA: The McGrawhill Series in Economics.

Schmidt-Hebbel, K., Serven, L., \& Solimano, A. (1996). Saving and investment: Paradigms, puzzles, policies. The World Bank Research Observer, 11(1), 87-117.

Singh, T. (2010). Does domestic saving cause economic growth? A time-series evidence from India. Journal of Policy Modeling, 32(2), 231-253.

Snowdon, B., \& Vane, H. R. (2005). Modern macroeconomics: its origins, development and current state. Cheltenham, UK: Edward Elgar Publishing.

Solow, R. M. (1970). Growth theory: an exposition: The Radcliffe lectures delivered in the University of Warwick, 1969. Oxford: Clarendon Press.

The Global Competitiveness Report (2010-2017). Klaus Schwab, World Economic Forum.

World Bank (2016). World Development Indicators. Retrieved from: http://databank.worldbank.org/data/reports.aspx?source=2\&Topic=3

Zivot, E. \& Andrews, D. W. K. (1992). Further evidence of the great crush, the oil price shock and the unit root hypothesis. Journal of Business and Economic Statistics, 10, 251-70. 
Figures

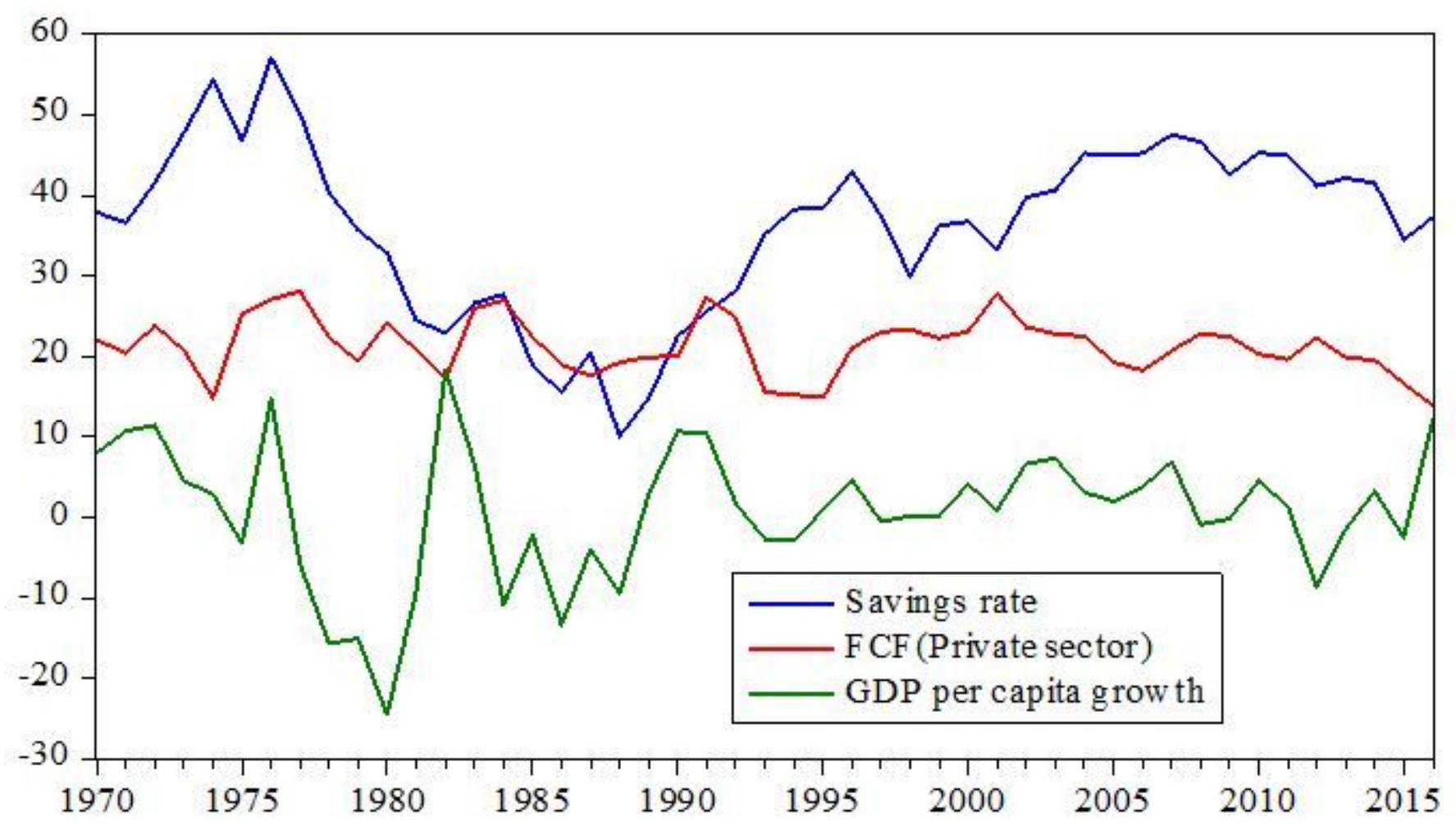

Figure 1

The trend of savings rate, fixed capital formation, and GDP per capita growth in Iran (from 1970-2016) Source: World Development Indicators

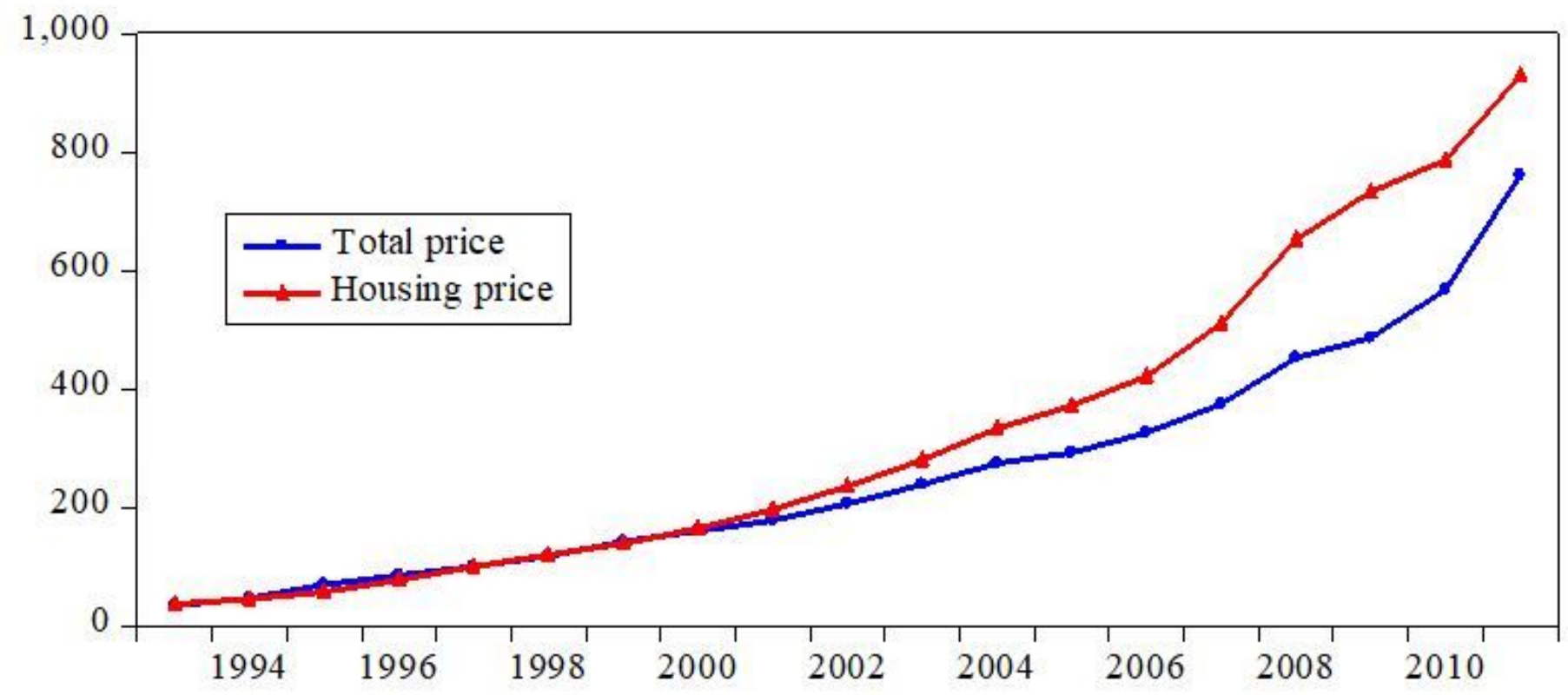

Figure 2 
The trend of housing price compared to the total price index Source: Central Bank of Islamic Republic of Iran

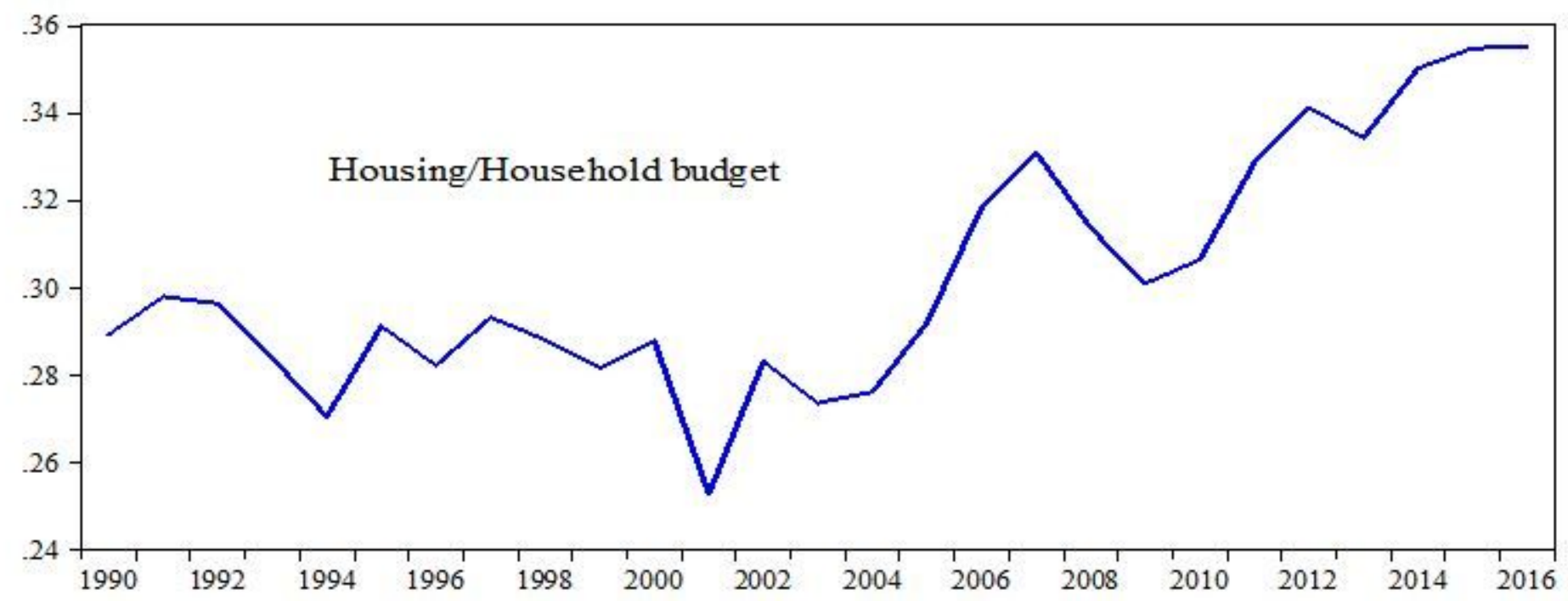

\section{Figure 3}

The share of housing in Iranian household budget without housing rent consideration in urban area (1990 - 2016) Source: Central Bank of Islamic Republic of Iran
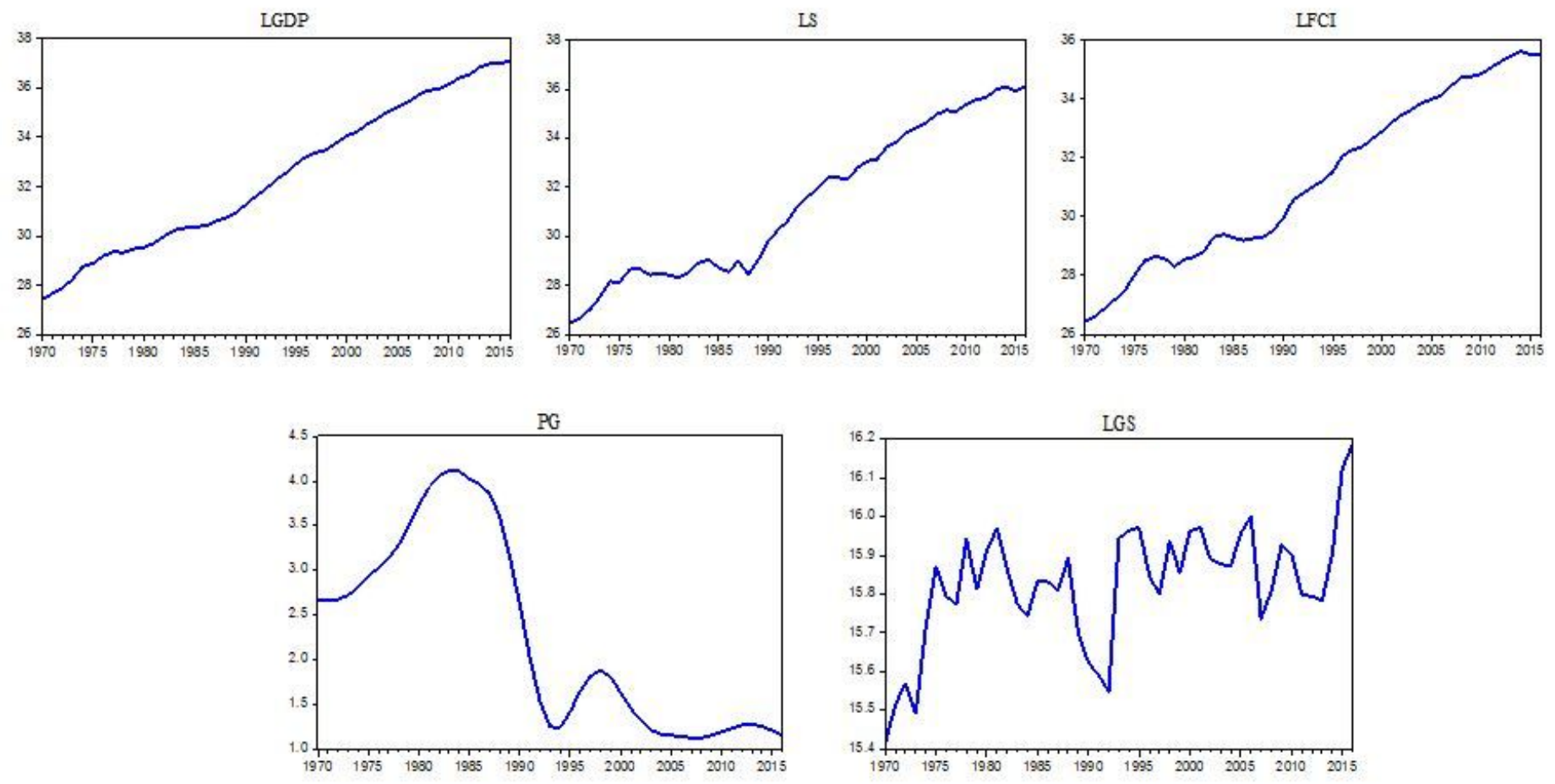

Figure 4

Time series trend of the variables (1970 - 2016) 

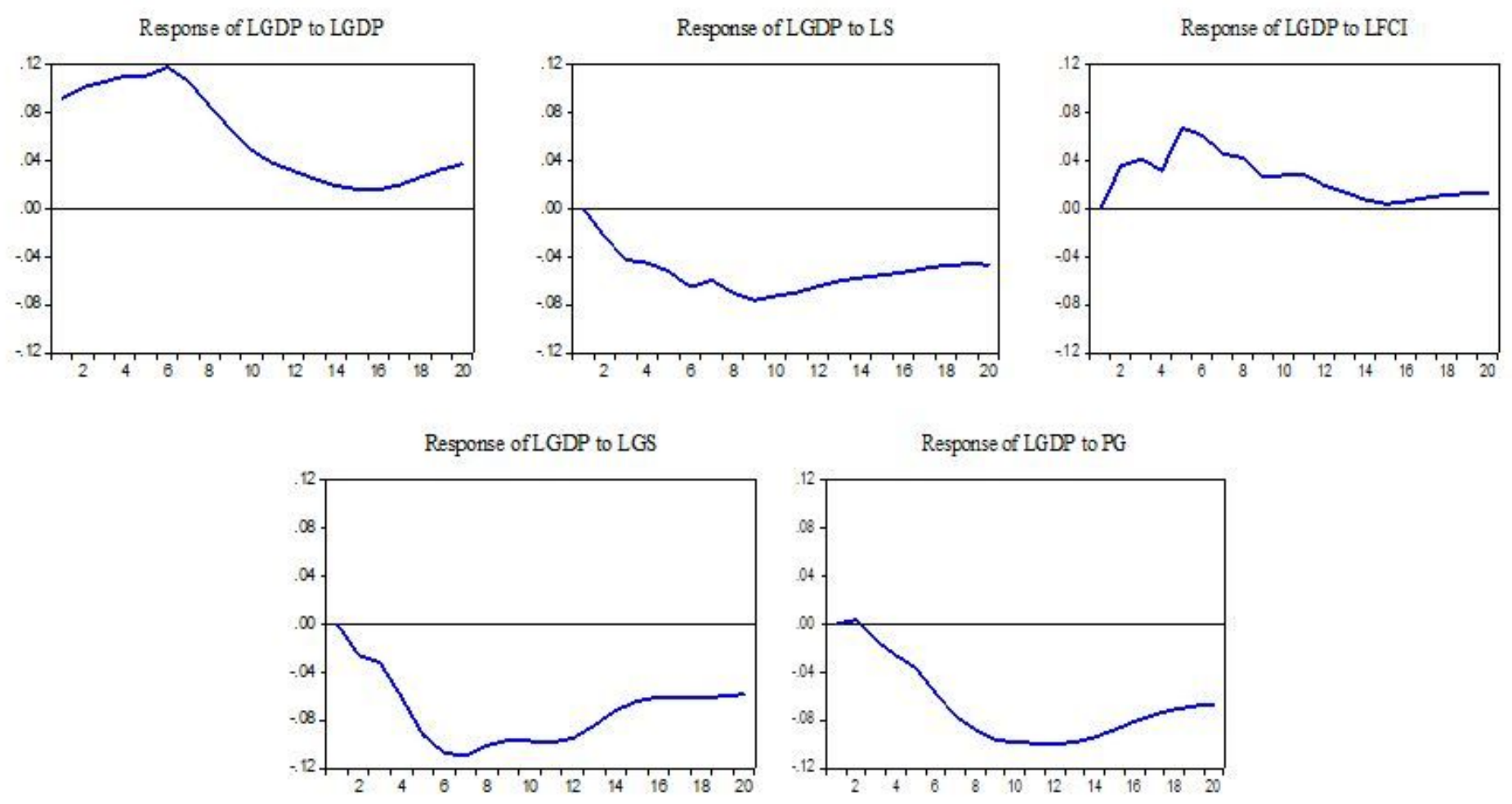

\section{Figure 5}

Impulse response function for dependent variable LGDP
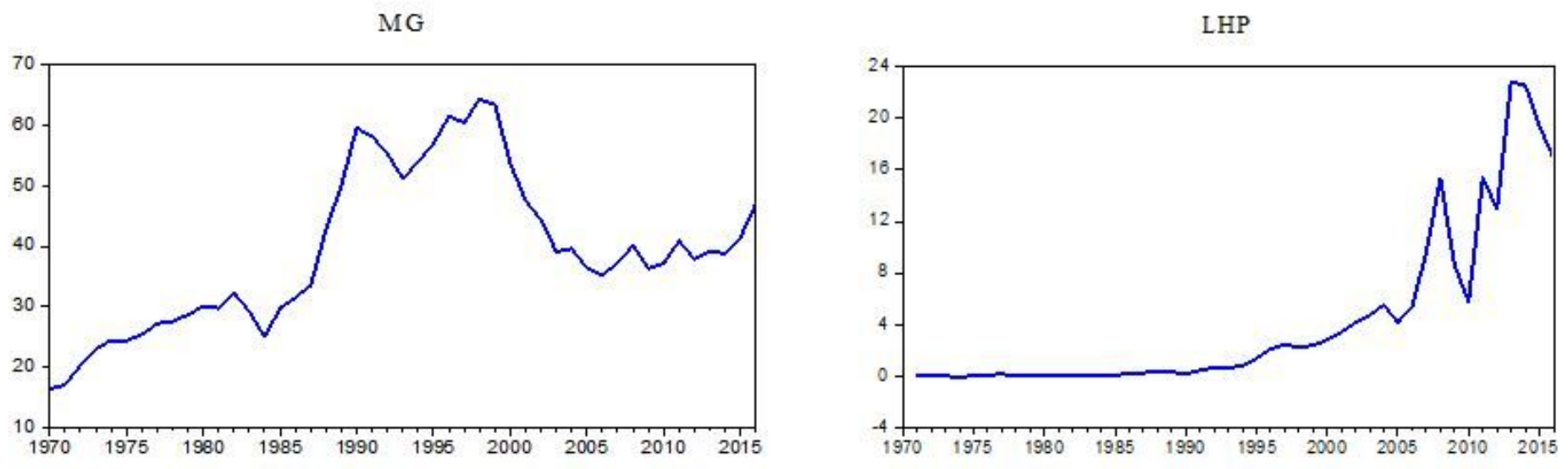

Figure 6

the trends of MG and LHP in period of 1970-2016. 

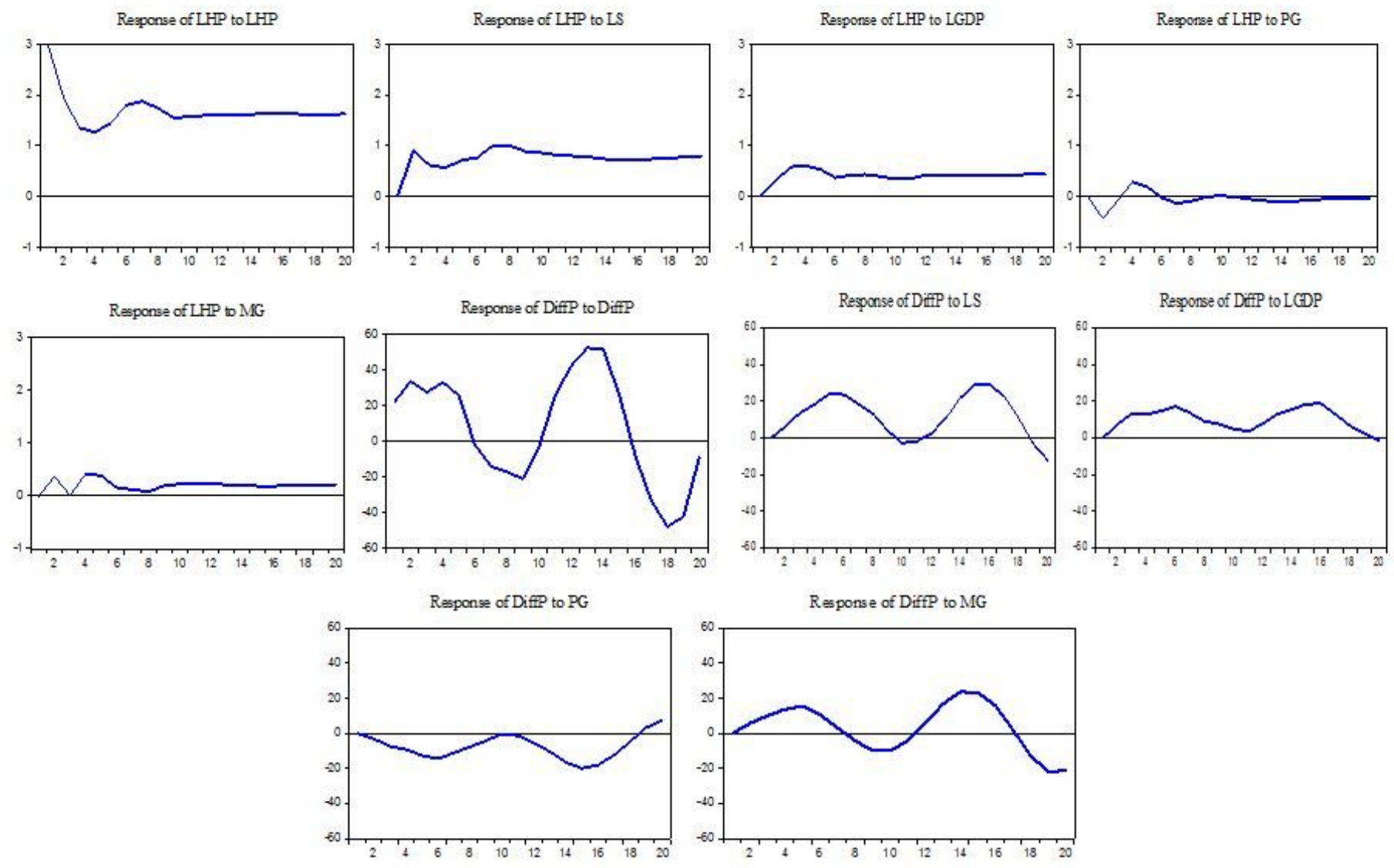

Figure 7

Impulse response function for dependent variables LHP and DiffP 